\title{
How to deal with conflict without using violence? Analysis of the colombian state and the law of victims, taking away arguments to illegal armed groups
}

¿Cómo hacer frente a un conflicto sin usar la violencia? Análisis del Estado Colombiano y la Ley de víctimas, quitando argumentos a los grupos armados ilegales.

DOI: 10.21803/adgnosis.v8i8.356

\begin{abstract}
The Colombian conflict has been one of the longest running disputes in the Western world. Although the signing of the peace treaty in 2016 gave hope back to the territory, this process did not happen overnight, so it was necessary to go through a historical journey to get the results today, where one of its fundamental milestones was the law of victims and the framework for peace. Through a review of the literature, this article seeks to analyze the impact on the Colombian conflict and the dynamics of the actors involved from the perspective of the law of victims. Among the most significant findings is that the Victims' Law should not be seen as a panacea to solve all the country's problems. Few recognize that it is a first step in the right direction, and the government's courage to take it must be stressed. In that sense, the authorities must show good intentions, imagination and political will to allow the military response on the one hand, and generate and implement initiatives and policies with facts on the other hand.
\end{abstract}

Keywords: Armed conflict in Colombia, victims' law, peace, reconciliation

\section{Resumen}

El conflicto colombiano ha sido una de las disputas más largas del mundo occidental. Aunque la firma del tratado de paz en 2016 devolvió la esperanza al territorio, este proceso no se produjo de la noche a la mañana, por lo que fue necesario hacer un recorrido histórico para obtener los resultados hoy, donde uno de sus hitos fundamentales fue la ley de víctimas y el marco de la paz. A través de una revisión de la literatura, este artículo busca analizar el impacto en el conflicto colombiano y la dinámica de los actores involucrados desde la perspectiva del derecho de las víctimas. Entre los hallazgos más significativos se encuentra que la Ley de Víctimas no debe ser vista como una panacea para resolver todos los problemas del país. Pocos reconocen que es un primer paso en la dirección correcta, y hay que destacar el valor del gobierno para darlo. En ese sentido, las autoridades deben mostrar buenas intenciones, imaginación y voluntad política para permitir la respuesta militar, por un lado, generar y aplicar iniciativas y políticas con hechos por otro lado.

Palabras clave: Conflicto armado en Colombia, derecho de las víctimas, paz, reconciliación
Nelson Cano Holguín'

nelson.canoh@oulook.com

\section{Cómo citar este artículo:}

Cano N. (2019). How to deal with conflict without using violence? Analysis of the colombian state and the law of victims, taking away arguments to illegal armed groups. 8(8), p 11- 20. DOI: 10.21803/adgnosis.v8i8.356

1 Administrador de empresas Universidad Militar Nueva Granada, MBA. in International Conflict and Security with International Migration University of Kent, ORCID https://orcid.org/0000-00019425-5810 


\section{Introducción}

The states are quite reluctant of recognizing the existence of armed conflicts within their territory, and usually try to tackle the problem from a rather ambiguous optical, first refused to recognize the conflict with the false premise that by doing so, would give political recognition to the insurgent group and secondly, fit all its provisions and internal structure to deal with the conflict.

The inadequate approaches to resolve the armed struggle, entails the design of wrong policies that creates more problems rather than fixes it, and can generated the conditions for its prolongation which is perhaps the situation happened in the Colombian conflict.

For over four decades, the Colombian state, under the influence of the United States and especially in the period of the Cold War, cataloged the internal conflict, not as a social problem, but as a threat to national security framed within an international conspiracy led by the Soviet Union to establish a communist government.

According this approach, in the 60s the doctrine of "national security" was designed which gave to the military the entire responsibility to resolve the conflict, without a clear political address, which has shown to be fruitless, subjecting the civilian population to unimaginable, sufferable atrocities during this time by the different actors involved, which leaves a dishonorable record of more than $25 \%$ of the population directly or indirectly affected.

In 2011, for the first time in history, the Colombian state recognized the existence of internal conflict, putting victims at the center of public debate, creating a law that not only gave them recognition, but also focused on the comprehensive repair and restoration of rights.

This legislation, which is in accordance to international standards of justice and reparation for victims, tackled directly several of the social problems asso- ciated with the internal conflict, and compelled the Colombian state to assume theirs responsibilities, facing many of the social claims used by the guerrillas to justify their struggle, which dismissed their legitimacy and took their arguments, putting them in a dilemma.

This article aims through a historical account of before and after mentioned law, to analyze the impact on the Colombian conflict and the dynamics of the actors involved. Also, it intends to show how these types of initiatives are very efficient alternatives that contribute to setup the conditions for resolve the conflict more efficiently than through the use of weapons and violence, attacking their roots and causes.

In that order of ideas we start from a theoretical and historical framework where we briefly outline the context of the Colombian armed conflict and the attempts to achieve peace prior to 2011, then we propose how the law of victims arose, how it resolves some of the problems that gave rise to the armed conflict and the path it has taken at present and finally we propose how this law offers a constitutional structure that, although it does not resolve the basic problems of the conflict, makes it possible to build the path to peace, presenting conclusions and raising discussions.

\section{Background Theory And History}

\section{Context of the conflict}

Nowadays, there is no general consensus among scholars on the exact origins of the Colombian conflict, there are three historical moments that are considered by experts as the causal thereof. Some argue that its origins date back to the decade of the 30 , for land and political disputes between the two traditional parties, the Liberal and Conservative (Restrepo et al., 2003).

However, many others place their causes in the riots which take place after the assassination of liberal leader Jorge Eliecer Gaitan in 1948, triggering a wave of protests from the lower classes and violent repression by the government throughout the country, for a 
period which extends to 1953 and is called "la Violencia” (violence) (Acosta Núñez, 2014; Schuster, 2009).

And others argue that the beginning of the insurrection are given for the attack by government forces, some peasant farming communities of communist ideology, which had been established as organizational forms of exploitation of the earth, in isolated areas of the territory national after the pacification of the country between 1953 and 1957 by the government of General Rojas Pinilla (Garcés, 2005). However, there is a common thread in all these events and a common denominator: the social exclusion and demands for access to land by peasants.

Another determining factor for the emergence of guerrilla movements was the exclusion to which were subjected some political parties like the Colombian Communist Party and the Liberal Party who did not identify with the policies of the moment, which generated social tensions and political, and as a consequences did not allow access to political power to those movements of different thinking (Restrepo et al., 2003).

During the decade of 60's, social discontent and political exclusion, led many to see in the armed struggle, a chance to access the power as with the Cuban revolution, which encourage the revolution in the country (Acosta Núñez, 2014; Pécaut, 2008).

In less than a decade, many guerrilla groups were created in various regions of the country with different trends. Thus for 1964 appear on stage the Colombian Revolutionary Armed Forces (FARC), (Restrepo etal., 2003; Schuster, 2009; Garcés, 2005) with communist ideology, they call themselves as a political-military group using weapons and violence to achieve political objectives (Rosero, 2011; Sánchez \& Palau, 2006), its purpose is to overthrow the government and establish a communist system that aimed for the rights of peasants and the working class (Ibañez, 2009; Garcés, 2005; Pécaut, 2008).

In 1964 makes its appearance the Army of National Liberation (ELN) with an ideology and Castro trend, based on the experience of the Cuban revolu- tion, and in 1968 the Popular Liberation Army (EPL) with a Maoist trend. Then other movements like the M-19 in 1973 and the Quintin Lame were created among many others of less importance and significance in different periods of time.

Within this scenario, it is possible to understand something about of the complexity of a conflict that has hit the society and the country for over 50 years (Sánchez \& Palau, 2006) being costly not only in economic terms, but affecting the civil population and loss of capacity development and productivity.

However, from this whole range of illegal groups that have existed throughout the conflict, which still remain in weapons capable to challenge the state, by guerrilla groups are the (ELN) and the (FARC) this last is the main and largest insurgent group (Di Giunta et al., 2011), which is currently conducting a peace process negotiation with the Colombian government.

The great challenge facing the state are the groups of heavily armed criminal's organizations called criminal gangs (BACRIM), dedicated solely to drug trafficking and extortion, which are somehow the result of the demobilization of the AUC by the government in subsequent years.

Throughout all this period of armed confrontation, drug trafficking has played a key role, as the resource of all stakeholders to a greater or lesser extent have been involved (Berdal \& Malone, 2000; Murshed \& Tadjoeddin, 2009; Restrepo et al., 2003; Amuzegar, 2002; Ganesan \& Vines, 2004) the various armed groups also stand for committing serious abuses of human rights of the civilian population.

\section{Policies addressed to solve the conflict before 2011}

To address the problem of insurgency, the various governments gave importance to the military solution, trying to defeat the insurgency by the state military apparatus and confrontation, all this framed within the "National Security Doctrine" (Rosero, 2011).

The National Security doctrine established that 
the emergence of insurgency in the country was not the result of complaints or unmet social needs of part of the civilian population, it was an international conspiracy framed in the Cold War, led by communism to undermine democracy in Latin America, (Jimenez 2009; Rosero 2011), a fairly consistent political position with the United States. This approach, closed the spectrum of possibilities to give a comprehensive solution to the conflict, letting to the military almost exclusive responsibility of its solution. Focus in a military defeat of the insurgents or a negotiation process as a result of the operations against them, his thinking dominated between the mid-70s and early ' 80 s (Jimenez, 2009)
In this context, every Colombian government since 1982, from one way or another has tried to negotiate peace with the insurgents (Acosta Núñez 2014), while increasing military operations. However, all approaches until the end of the next decade, followed the same pattern, a law empowering the government to grant amnesties and pardons to the insurgents who were demobilized and surrendered their weapons.

During the administration of Julio Cesar Turbay (1978-1982) Congress gave faculties the government through law 37 of 1981 to grant amnesty to the rebels but no results. Later in 1982 during the administration of Belisario Betancourt Cuartas (1982-1986) Congress issued the law 35 of 1982 whereby an amnesty is enacted with regulations aimed at restoration and preservation of peace. During this period peace negotiations between the government and the guerrillas began, resulting in the creation of a political movement to represent the interests of subversion, called Patriotic Union (UP), most of its members were killed (Acosta Núñez 2014; Guerrero 2003), which created a climate of distrust that ended negotiations.

In December 1989, during the government of Virgilio Barco Vargas (1986-1990), Congress authorizes the President by Law 77 of 1989, to grant pardons and cease criminal action against illegal actors. This legal framework allowed the demobilization of the M-19 guerrilla group the March 9, 1990.
In January 1991 during the administration of Cesar Gaviria Trujillo (1990-1994), through Presidential Decree No. 0213 of 1991 and supported in the Constitution, the national government took steps to allow the restoration of public order. As a result of this decree, peace agreements between the government and various guerrilla groups were signed: on January 25, 1991 with the Revolutionary Workers Party (PRT), on February 15, 1991 with part of the People's Liberation Army (EPL), and in May 1991 with the Armed Movement Quintin Lame (MAQL). However the main guerrilla groups like the FARC and the ELN were not part of the peace agreements, and after a few approaches of negotiation between the Colombian government and these guerrilla groups took place in Havana and in Tlaxcala Mexico, but the climate of distrust grew up after some leaders of the newly demobilized guerrillas were killed (Guerrero 2003).

The government of Andrés Pastrana (1998-2002), began one of the processes of negotiation of peace most famous in recent history of the country with the FARC guerilla, called "Caguan dialogs", where the guerrillas were granted with the demilitarization of a zone of $42,000 \mathrm{~km} 2$, which was used by them to strengthen militarily and commit a series of abuses against civilians, which finally in 2002 after four years of negotiations, ended with the patience of government and peace talks (Cano Roldán \& Caro Garzón 2011).

The change of government modifies the political situation, after the disappointment in public opinion caused by the failed peace process with the FARC, the new government of President Alvaro Uribe Velez (2002- 2006)(2006-2010) performed a demobilization negotiation process with the paramilitary groups (AUC) (Buitrago 2006). A new legal framework was created, it was the law 975 of 2005 called justice and peace, which allowed the negotiation of demobilization of armed actor's different to the guerrilla groups. For the first time it begins to incorporate into domestic legal order terms such as transitional justice, accepting the principles of truth, justice and reparation for victims, (Escalante 2013).

As a result of this process of submission to justice 
and surrender of arms by these groups, between 2003 and 2006, more than 30,000 men and women of these groups were demobilized (Feldmann \& Hinojosa, 2009; Cano Roldán \& Caro Garzón 2011), but at the same time, government hardens his position with the guerrillas, increasing military actions throughout the national territory.

To this point, all efforts for the demobilization of illegal armed groups have not had the best balance, although it has decreased the number of actors and armed men, this has not been reflected in an actual decrease in levels intensity of violence or internal conflict in the country.

The administration of President Juan Manuel Santos (2010-2018), has initiated rapprochement with the guerrilla groups of the FARC and the ELN, to seek a negotiated peace settlement, approaches that started in secret and resulting with the FARC in the establishment of a formal negotiating process in Havana Cuba, a country that together with Norway served as facilitators of the process which was formally opened on October 18, 2012, with a specific agenda and clear negotiation rules.

With the Liberation National Army (ELN) still continue the rapprochement with the aim of establishing a table parallel to the FARC negotiation, in order to start a peace process with defined agenda.

The legal framework that allows the government to conduct these negotiations with armed guerrilla groups, is the legislative act No. 01 of July 31, 2012, where the Congress of the Republic establishes legal instruments of transitional justice to seek the termination of the armed conflict.

Other law that has paved the way to advance the negotiations with rebel groups and which is the main object of study of this paper, has been the law 1448 of 2011 also known as the law of victims and land restitution, which create mechanism for care, assistance and reparation to victims of the Internal armed conflict and other provisions.

\section{Methodology}

With the objective of analyzing the impact on the Colombian conflict and the dynamics of the actors involved from the perspective of victims' rights, it is proposed to measure the progress and impact that scientific publications have had with respect to these aspects in electronic media such as articles, books and publications in Journals.

Through a review of the literature based mainly on primary sources such as journals, articles and scientific publications, a systematic sequence of steps is followed so that the impact of the Colombian conflict and its actors can be analyzed from the perspective of the law of victims. This analysis consists of the search in databases such as Scopus and Wos, where articles with high citation rates, outstanding authors as well as high impact scientific journals were selected. The information was then analyzed and systematically constructed to provide a theoretical and empirical context and from there to determine the impact of the victims' law as a first step towards peace in Colombia and draw some conclusions and discussions for future research.

\section{Findings}

As was observed in the previous section, all efforts for the demobilization of illegal armed groups have not had the best balance, although it has been decreased the number of actors and armed men, this has not been reflected in a decrease in levels intensity of violence of the internal conflict in the country.

All efforts within these peace processes developed between the government and the various illegal armed groups throughout the recent history of the country, were conducted to reduce the intensity of the conflict through the demobilization and reintegration of combatants. But there never was a comprehensive peace policy which integrated the victims of conflict or encouraged the demobilization to not fall back into the dynamics of war, which is what eventually happened and therefore the factors that generated the conflict remain. The state was not able to assume their responsibilities to the demobilized, victims, civil society 
and even in the territorial control to be exercised once the different groups were attending the peace agreements and reintegration.

As a result, the cycle of violence continues, within a population that still feels violated their rights and in an atmosphere of poverty and limitations. With state incapable of guaranteeing minimum rights, especially in the more remote areas of the country, which remain under the abuse of illegal armed groups.

After the demobilization of paramilitary groups between 2005 and 2006, the government entered a new dynamic. For the first time within the legal framework that allows the demobilization of these criminal structures, it begin to talk to the country about the need for transitional justice, enabling the state to create the necessary mechanisms to begin to dismantle the conflict comprehensively in consistence with the provisions and standards of justice, truth and reparations.

However, that is until 2011 that Congress initiated to create the legal tools that allowed the government to tackle the roots of conflict. The adoption of the law 1448 of 2011 is an example of this. It is considered one of the most important legal phenomena in the history of the conflict, seeking national reconciliation (González Pulgarín \& Henao Guzmán 2012).

This act as the representative of the program for development of the United Nations in Colombia said "is not a perfect law and certainly some aspects could be improved to better adherence to international guarantees and participation of victims standards. But it is a law that gives a decisive step for Colombia.” (Programa Naciones Unidas para el desarrollo, PNUD 2011)

There are several aspects to highlight in this law but three are the most important, the first is the recognition by the Colombian state that there is an armed conflict.

The second important aspect and as a direct consequence of the above statement, recognizing the internal conflict, the state also recognizes victims which are defined in the law, allowing them full recognition of their rights and therefore assumes their responsibilities as part of the conflict. In addition, it does not discriminate whether the perpetrators were paramilitaries, guerrilla groups or agents of the state.

Similarly, the state commits itself to performing full reparation that is not only in economic terms. In this case, victims are entitled to know the truth and justice. Therefore, should establish judicial and administrative mechanisms that individually or collectively give them access to the benefits of the law and guarantee of non-repetition.

And the last relevant event is the restitution of land to victims of violence displaced peasants. It is estimated that the internal conflict in Colombia has directly affected $10 \%$ of the civilian population that are ultimately the victims of this tragedy (López 2008). Colombia occupies the dishonorable second place worldwide among the countries with the largest displaced population (IDP). With an amount of around 5 million displaced persons and dispossession of land of more than 5.5 million hectares, which have been usurped by force to the peasants and small producers, for any of the illegal armed groups (Garay, 2009).

This law is valid for 10 years since its enactment on June 10, 2012 and the costs of implementation are covered by a document of economic policy that ensures the resources that state should invest for proper implementation and achievement of the objectives.

The challenge of the law, as experts say will be in its implementation, it is a law that seeks to guarantee certain rights in a context of conflict and where very likely to land restitution is going to touch big interests. In addition, many perpetrators have the ability to cause damage and fear of the victims if they are not given adequate protection.

\section{The Law Of Victims in Colombia and the conflict.}

It is not easy for a country that has been so long in conflict, begin to change the dynamics of war. For a long time the Colombian government did not even 
acknowledge the existence of a conflict (Von der Groeben 2011; Navia 2008) the official position was always to face a communist threat in the beginning, and after the events of September 11, his speech focused on demonstrating that he was facing a terrorist threat. Which is quite common in political discourse following the governments to minimize the opponent (Droege 2007), considering that in between there are issues of sovereignty and international reputation (Momtaz 1999).

All this climate of tension wards off the parties involved in the conflict and create distrust between them. Especially in a country so as polarized ideologically as Colombia, with high levels of inequality. In which none of the armed actors whether they be state or guerrilla or paramilitary groups, have the backing of the civilian population, and where the armed path that has been chosen to address the problem has not been the most effective, since the indicators of violence and perceptions of safety of citizens is negative.

Moreover, neither in the medium or long term, it is the possibility that any of the parties nor ideologically or militarily, be imposed to the opponent in the combat area and in the political arena.

Therefore, the pursuit and implementation of initiatives and policies that require different approaches to the dismantling of the conflict, not only represent a challenge, but also may be politically inappropriate and whoever assumes it must be clear that the consequences of poor implementation, can be worse than the continuation of the conflict.

Recognizing the internal armed conflict in the country, the state sets several precedents, the first is that it takes its responsibility to the victims as an actor and part thereof.

In a second step demystifies a statement that made a career throughout the history of the conflict. That admitting the existence of the conflict, would give political status to the opponent, which is not fully founded, and finally, allows to give clarity to the procedures and rules governing war. that is allows framing the actions of the security forces especially the military to combat illegal armed groups and also the treatment that should be given to the guerrillas captured or demobilized

The law of justice and peace, summarizes the intention of the state to seek formulas to dismantle the roots of the problem, attacking one of the foundations on which has historically based conflict such as land and its bad distribution (González Pulgarín \& Henao Guzmán 2012).

When the Colombian state assumed responsibility for recognizing the rights of the victims of the conflict and in addition, repair them integrally for the damages that historically have suffered accepting the principles of truth, justice and reparation. And also taking appropriate measures in order to restore the land for which in many cases they have been displaced or killed, is indirectly depriving guerrillas some of the strongest arguments that have been used to justify armed struggle against the state.

It is a very strong message that the government sends to the civil society, which shows closeness to social problems and a clear intention to seek substantive solutions to the conflict and its roots to prevent future recurrence.

The United Nations through the program manager for development in Colombia, has expressed well when he says about the law of victims "has been classified as a step towards the search for peace, the protection and guarantee of rights victims of Colombia and a turn of the policies of the Colombian state in favor of the rights of victims. However, it warns that has some gaps and further recognizes that it is not a perfect law (Programa Naciones Unidas para el desarrollo, PNUD 2011).

The measures taken by the law, are a step in the right direction towards ending the conflict which together with the military action, seeks to close spaces and delegitimize the insurgency before national and international public opinion, which necessarily will bring consequences in the near future within the dynamics of the conflict. 
The law of justice and peace although allowed the demobilization of over 30,000 combatants and ended paramilitary structures as an organization, do not help reduce levels of violence, considering it was not wide enough to shelter other actors in the conflict. It was a law designed especially for this process, leaving a balance on red with victims.

As a result of poor implementation, many paramilitary structures that should disappear with demobilization, became criminal organizations involved in drug trafficking. With influence in the same regions where they carried out their criminal activities, which made communities of these places remain under control and the threat of their aggressors.

Civil society was not prepared to receive these demobilized, many of whom remained to live in the towns where they carried out their criminal activities, were rejected by the community because the accumulated resentment. The state failed to achieve the principles of truth and reconciliation (Agudelo \& Walker 2010) between victims and perpetrators, which becomes an indignation and rejection that often forces demobilized armed groups and retook their criminal practices.

The issue of reparation to victims was half, many goods delivered by the perpetrators to repair their victims had legal problems and was not possible to use them. Many other goods were hidden by proxy to prevent them be known for the authorities. In short, even symbolic reparation was not sufficiently applied, creating a feeling of discontent among victims resulting in loss of confidence in the process and in government.

On the other hand as a positive experience of the law of victims, it began to be implemented in the country a model of transitional justice in which the demobilization of paramilitary groups, it was a first step in a model of transition from a state of conflict to one of post-conflict, which is a challenge for the state because the conflict persists (García-Godos \& Lid 2010). It can be seen in cities among demobilized from illegal groups and citizens victim of them.

The law of victims meanwhile, is only in its imple- mentation period, and it is still too early to draw conclusions, which is whether it should learn from past experiences to ensure non-repetition of mistakes.

Another important issue addressed by the law of victims is that members of the security forces have also been considered as victims, whether as a result of violence of the enemy have been physically or psychologically affected, they can be compensated by the state. Which it is something innovative that although it is still generating controversy, is positive for matters of universality, because a military civil continues being a citizen and therefore is protected by law.

The experiences of Colombia in its peace policies during the past 25 years have not been the result of an integrated policy aimed at dismantling the conflict and allow national reconciliation. However, the trend is in the future and based on the experiences of the past processes, aims for the search for definitive cessation of armed confrontation.

\section{Conclusions and Discussion}

One should not pretend that the Victims Law is the panacea that solves all the problems of the country. Few recognize that it is a first step in the right direction, and we must highlight the courage of the government to take it. And start looking for other approaches to help take away from the illegal actors in the conflict, the arguments used to continue the fight armed and thus force them to cease the use of violence as a political tool.

For the first time, the Colombian government accepts the occurrence of a conflict, assumes its responsibility and is committed to designing policies and programs for comprehensive care for the victims of the armed conflict. This should be the basis for future initiatives, avoiding implementing policies contrary to those provisions.

In the future, should learn from the experiences gained by the state and society with the various initiatives that have been implemented. The most important being the law of justice and peace and the law 
of victims, which can be considered as a laboratory of good intentions that are the basis for subsequent processes and initiatives.

To find solutions for the armed conflict, the authorities must demonstrate good intentions, imagination and political will to enable the military response aside, generate and implement initiatives and policies with facts, distort the arguments used by the guerrillas to continue armed struggle.

In Colombia they have not been able to generate the conditions for reconciliation and termination of the conflict. There has not been a comprehensive policy that seeks to armed violence. All agreements have been partial and seeking to generate political acceptance with the current government, which should be reviewed in the future. Seeking to establish a state policy toward peace to be sustained over time, rather than an initiative of individual governments.

Finally, it should be noted that the peace initiatives that are generated and seek to end the conflict, should be framed within international standards of justice, seeking compliance with the principles of truth, justice and reparation. Where victims have an important role and the conflict is addressed holistically to disarticulate its causes not only disarming the combatants, but the hearts and minds of civil society.

\section{Referencias}

Acosta Núñez, M. L. (2014). Introducción a los diálogos de paz en Colombia, un acercamiento histórico a los intentos de solución del conflicto. http://hdl.handle.net/10654/11237

Agudelo, G. D., \& Walker, C. A. (2010). Ley de justicia y paz, un balance de su primer lustro. Perfil de Coyuntura Económica, (15), 59-77. ISSN 1657-4214.

Amuzegar, J. (2002). Plan Colombia. SAIS Review, 22(1), 97-102. https://doi.org/10.1353/sais.2002.0007

Berdal, M., \& Malone, D. (2000). Greed \& grievance: Economic agendas in civil wars. E.E.U.U: Lynne Rienner Publishers, ISBN: 9781555878689

Buitrago, F. (2006). La política de seguridad democrática 20022005. Revista Análisis Político, 19(57), 3-30. http://www. scielo.org.co/scielo.php?script=sci_arttext\&pid=S012147052006000200001\&lng=en\&tlng=en.

Cano Roldán, M., \& Caro Garzón, O. A. (2011). The great difficulties of the administrative reparation of the victims of the violence in Colombia some comments with respect to the implementation of the decree 1290 of 2008. Revista de la Facultad de Derecho y Ciencias Políticas, 41(115), 451-97. http:// www.scielo.org.co/scielo.php?script=sci_arttext\&pid=S0120$38862011000200008 \& \operatorname{lng}=\mathrm{en} \& t \operatorname{lng}=\mathrm{en}$.

Di Giunta, L., Uribe, L. M., \& Araque, L. A. (2011). Attributions and attitudes of mothers and fathers in Colombia. Parenting, 11(23), 116-28. https://doi.org/10.1080/15295192.2011.585554

Droege, C. (2007). Interplay between international humanitarian law and international human rights law in situations of armed conflict. ISR.L.REV, 40(2), 310-355.

Escalante, E. L. (2013). Tierras despojadas, ¿derechos restituidos? :(Des) encuentros acerca del problema de la tierra en Colombia en un escenario de" justicia transicional. Colombia: Universidad de Antioquia, Facultad de Derecho y Ciencias políticas. ISBN:9789588790831

Feldmann, A. E., \& Hinojosa, V. J. (2009). Terrorism in Colombia: Logic and sources of a multidimensional and ubiquitous 
phenomenon. Terrorism and Political Violence, 21(1), 42-61. https://doi.org/10.1080/09546550802544656

Ganesan, A., \& Vines, A. (2004). Engine of War: Resources, Greed, and the Predatory State, Published by The Human Rights Watch. https://www.reworld.org/docid/402ba8804

Garay, L. J. (2009). El reto ante la tragedia humanitaria del desplazamiento forzado: Reparar de manera integral el despojo de tierras y bienes. Colombia: Comisión de Seguimiento a la Política Pública sobre Desplazamiento Forzado. ISBN: 978958-98781-8-

Garcés, L. (2005). Colombia: The link between drugs and terror. Journal of Drug Issues, 35(1), 83-105. https://doi. org/10.1177/002204260503500104

García-Godos, J., \& Lid, K. A. (2010). Transitional justice and victims' rights before the end of a conflict: The unusual case of Colombia. Journal of Latin American Studies, 42(03), 487-516. https://doi.org/10.2307/40984893

González Pulgarín, J. J., \& Henao Guzmán, J. P. (2012). A new form of concentration of land in Colombia: Law 1448 of 2011. Ecos De Economía, 16(34), 75-109. http://www.scielo.org.co/scielo. php?script=sci_arttext\&pid=S1657-42062012000100004\&ln $\mathrm{g}=\mathrm{en} \& \mathrm{tlng}=\mathrm{es}$.

Guerrero, V. (2003). Breve historia de las amnistías e indultos en Colombia. Foro Constitucional Iberoamericano, 6(1), 212-230.

Ibañez,A. M. (2009). Concentration of rural property in ColombiaPRIO.http://www.prio.org/Publications/Publication/?x=7219

Jiménez, C. (2009). Implementation and instrumentalization of the national security doctrine in Colombia (1978-1982): Effects on human rights problems. Reflexión Política, 11(22), 158-174. https://www.redalyc.org/articulo.oa?id=110/11012487012

López, O. R. (2008). Estéticas del desarraigo. Fondo Editorial Universidad EAFIT. ISBN: 9588281938,9789588281933

Momtaz, D. (1999). War crimes in non-international armed conflicts under the statute of the international criminal court. Yearbook of International Humanitarian Law, 2, 177-192.
https://doi.org/10.1017/S1389135900000416

Murshed, S. M., \& Tadjoeddin, M. Z. (2009). Revisiting the greed and grievance explanations for violent internal conflict. Journal of International Development, 21(1), 87-111. https://doi. org/10.1002/jid.1478

Navia, R. (2008). ¿Hay o no hay conflicto armado en Colombia? Anuario Colombiano De Derecho Internacional-ACDI, 1, 139-59. ISSN 2145-4493

Pécaut, D. (2008). Las FARC: Fuentes de su longevidad y de la conservación de su cohesión. The FARC: Sources of their LongevityandCohesion”). AnálisisPolítico,21(63),22-50.http:// www.scielo.org.co/scielo.php?script=sci_arttext\&pid=S012147052008000200002\&lng=en\&tlng=es

PNUD. (2011). El ABC de la ley de víctimas. http://www.pnud.org.co

Restrepo, J. A., Spagat, M., \& Vargas, J. F. (2003). The dynamics of the Colombian civil conflict: A new data set Department of Economics, Royal Holloway University of London. https://ssrn. com/abstract $=480247$

Rosero, L. F. (2011). Colombia y los Estados Unidos en los inicios de la guerra fría (1950-1966) "Raíces históricas del conflicto armado colombiano". Memorias: Revista Digital de Historia y Arqueología desde el Caribe, 8(15), 47-74. http://www. scielo.org.co/scielo.php?script=sci_arttext\&pid=S1794$88862011000200004 \& \operatorname{lng}=\mathrm{en} \&$ tlng=es.

Sánchez, F., \& Palau, M. (2006.) Conflict, decentralization and local governance in Colombia, 1974-2004. CEDE. ISSN: 1657-7191

Schuster, S. (2009). El primer gobierno del frente nacional y el "problema” de la violencia (1958-1962). Iberoamericana, 9(36), 9-26. https://doi.org/10.2307/41676964

Von der Groeben, C. (2011). The conflict in Colombia and the relationship between humanitarian law and human rights law in practice: Analysis of the new operational law of the Colombian armed forces. Journal of Conflict and Security Law, 16(1), 141164.https://doi.org/10.1093/jcsl/krrO04 